\title{
ДИНАМІКА ПЛЕМІННОГО М'ЯСНОГО СКОТАРСТВА В УКРАЇНІ
}

\author{
Супрун Ірина Олександрівна \\ кандидат сільськогосподарських наук, доцент \\ Національний університет біоресурсів і природокористування України \\ ORCID: 0000-0001-8105-1923 \\ E-mail: isuprun@nubip.edu.ua
}

Довга Олександра Олексіївна студентка 2-го курсу факультету ветеринарної медицини Національний університет біоресурсів і природокористування України ORCID: 0000-0003-1682-0970 E-mail: jabri.kita@gmail.com

У вирішенні міжнародних і національних аграрних програм пріоритетним завданням є збереження генетичних ресурсів тваринництва і розробка шляхів їх ефективного використання, адже в світі спостерігається явна тендениія до скорочення породного складу одомашнених видів тварин. Тому метою наших досліджень був аналіз та висвітлення сучасного стану племінного м'ясного скотарства в Україні, а також характеристика вітчизняних порід, які є базою для племінної роботи та прогнозування їх значення у породотворному процесі. Для аналізу стану розвитку м'ясного скотарства в Україні було використано Державний реєстр суб'єктів племінної справи у тваринництві за 2015 - 2019 рр. Для дослідження використано методи системного узагальнення, графічний, аналітичний та порівняльно-статистичний. Проведено аналіз стану розвитку м'ясного скотарства в Україні. Показано, що найбільше поголів'я великої рогатої худоби м'ясних порід зосереджено на півночі та заході країни, де природно-кліматичні умови є сприятливими для створення розвинутої галузі м'ясного скотарства. Встановлено, що лідерами за чисельністю являються Волинська та Чернігівська області, а на даний час в Україні зареєстровано 52 племінні господарства, де розводять м'ясну худобу 11 порід. Найбільш чисельною серед імпортованих порід є абердин-ангуська порода. Серед вітчизняних порід найбільшою є питома вага волинської та поліської спеціалізованих м'ясних порід. Показано, що в умовах тривалої кризи за останні роки племінне м'ясне скотарство в Україні зазнало суттєвого скорочення чисельності поголів'я, звуження породної структури та зміни форми власності. Зокрема, за період з 2019 до 2020 року галузь м'ясного скотарства в Україні зазнала втрат чисельність племінного поголів'я загалом скоротилась на 7\%, а окремих порід як симентальської та південної м'ясної скоротилася на $32-60 \%$.

Ключові слова: м'ясне скотарство, порода, вітчизняна селекція, імпортні породи, племінне господарство, поголів'я.

DOI: https://doi.org/10.32845/bsnau.Ivst.2021.1.13

Збереження генетичних ресурсів тваринництва поруч із їх ефективним використанням залишається пріоритетним завданням міжнародних і національних аграрних програм.

Однією з причин прискіпливої уваги саме до цього питання стала явна тенденція до скорочення породного складу одомашнених видів тварин. Тому серед інших об'єктів збереження біологічного різноманіття визначених FAO в Україні $€$ м'ясне скотарство.

Скрутні економічні умови зумовлюють незадовільну реалізацію генетичного потенціалу заводських порід, що в свою чергу спричиняє нераціональну структуру племінного поголів'я. На сьогодні племінні господарства збиткові, не мають коштів для розширеного відтворення. Тому скорочується поголів'я худоби, збіднюється загальний генофонд, втрачаються окремі породи тварин. У сучасних нестабільних економічних умовах, саме на суб'єкти племінної справи покладається завдання стабілізації внутрішнього та зовнішнього ринку племінного скотарства. Подальший прогрес спеціалізованих порід вимагає спрямованої планомірної селекції.

Тому метою наших досліджень був аналіз та висвітлення сучасного стану племінного м'ясного скотарства в Україні загалом і характеристика вітчизняних та зарубіжних порід, які є базою для племінної роботи з ним та прогнозування значення окремих порід у породотворному процесі.
Матеріали та методи досліджень: для аналізу стану розвитку м'ясного скотарства в Україні було використано Державний реєстр суб'єктів племінної справи у тваринництві за 2015 - 2019 рр. Для дослідження використано методи системного узагальнення, графічний, аналітичний та порівняльно-статистичний.

Результати досліджень. Станом на 01.01.2020 року в Україні налічується 52 суб'єкти племінної справи, в яких утримується 25674 гол. племінної худоби м'ясного напряму продуктивності (з них бугаїв - 296 гол., а корів - 10654 гол.), у тому числі 18715 голів утримується у племінних заводах, 6959 голів - у племінних репродукторах. Племінну велику рогату худобу м'ясного напряму продуктивності розводять у 16 областях України. Найбільше поголів'я великої рогатої худоби м'ясного напряму продуктивності зосереджено на півночі та заході країни. Лідерами за чисельністю $є$ Волинська та Чернігівська області де зосереджено 8,286 та 5,177 тисяч голів племінної великої рогатої худоби м'ясного напрямку продуктивності (рис. 1).

Загалом племінні ресурси скотарства, з урахуванням природно-економічних зон в усіх областях України розподілені нерівномірно. У забруднених районах, на Поліссі їхня чисельність становить більше $50 \%$, у зоні Лісостепу - $30 \%$ у Степових регіонах - близько $20 \%$. Природно-кліматичні умови України є сприятливими для створення розвинутої

Вісник Сумського національного аграрного університету 
галузі м'ясного скотарства. В зонах Лісостепу й Степу господарства спеціалізуються на виробництві зерна, цукрового буряку. У структурі кормовиробництва близько 80 \% займає солома, інші грубі й соковиті корми, які найбільше раціонально можуть бути використані м'ясною худобою. Оскільки пасовища повинні бути невід'ємною складовою частиною галузі м'ясного скотарства для різних природно-кліматичних зон країни розроблені спеціальні технології створення й тривалого використання пасовищ на основі спеціально підібраних сортів трав.

Найбільше поголів'я великої рогатої худоби м'ясних порід зосереджено на півночі та заході країни. Лідерами за чисельністю являються Волинська та Чернігівська області де зосереджено відповідно 8,3 та 5,2 тисяч голів великої рогатої худоби м'ясних порід. У Львівській області налічується близько 1,8 голів м'ясної худоби. Серед центральних областей України м'ясне скотарство найбільше розвинуте в Черкаській (1,4 тис. гол.) та Житомирській (1,6 тис. гол) областях. У східних та південних областях поголів'я не досягає і 1 тис, за винятком Дніпропетровської області (1,6 тис. гол.).

Згідно із стратегічними даними найбільша кількість м'ясної худоби утримується в племінних господарствах Волинської, Чернігівської, Львівської, Дніпропетровської, Житомирської областей. Найменше племінне м'ясне скотарство розвинене у Рівненській, Херсонській, Донецькій та Полтавській областях. За даними аналізу, з 2019 до 2020 року суттєво (на 46-47\% )зменшилось поголів'я м'ясної худоби в Херсонській, Рівненській і кричуще (на 71\%) в Одеській областях. За останні роки реорганізувались чи втратили свій статус племінні репродуктори у Вінницькій, Рівненській, Чернівецькій, Черкаській областях. Натомість зросло поголів'я м'ясної худоби в Львівській та ІваноФранківській, Донецькій областях. Динаміка чисельності та розвитку порід за господарськи корисними ознаками потребує постійного детального аналізу і узагальнення селекційної інформації. Тому, ми проаналізували динаміку чисельності племінної м'ясної худоби усіх порід за останні 5 років Загалом порівняно з 2019 роком кількість племінної м'ясної худоби у племінних господарствах зменшилась на 7\%, а за останні 5 років поголів'я племінної м'ясної худоби зменшилось на 18,20\%. За цей період не підтвердили своїх племінних статусів, реорганізувались та збанкрутували 35 племінних господарств.



На сьогодні в Україні розводять м'ясну худобу 11 порід, з них наявно 6 порід м'ясної худоби вітчизняної селекції, а саме української м'ясної, волинської м'ясної, поліської м'ясної (в тому числі поліської м'ясної породи знам'янського типу), симентальської м'ясного напряму селекції, південної м'ясної, сірої української та 5 порід зарубіжної селекції: абердин-ангуська, шароле, лімузинська, світла аквітанська, гересрордська (рис. 2).

Найбільш чисельною породою м'ясної худоби в Україні $€$ абердин-ангуська. Питома вага чисельності корів породи складає 36 \%. Всього налічується 9345 голів племінної абердин-ангуської худоби, з них 102 бугаї та 3712 корів. 
Найбільшими господарствами з розведення абердин-ангуської породи є: ПП "Агро-Новоселівка, ТОВ "Бафффало", ТОВ СГП "Дніпро", ТДВ "К. Агропромтехніка", СВК "Лабунський", СГТОВ "Лище", ПАФ "Єрчики", ТОВ "Рачанське", ТОВ "Добробут", ТзОВ "Лан-Волинь", СТзОВ "Заповіт", СТОВ "Ратнівський аграрій", СВК "Україна", ДП "ДГ "Тучинське", СФГ "Серпанок", СГПП "Случ", ТОВ "СП"Агродім, СФГ "Манятин".

Поліська порода займає друге місце (15\%) за чисельністю серед поголів'я племінної м'ясної худоби. Загальна чисельність племінного поголів'я становить 3152 гол (2388 голів у племінних заводах, 764 голови у племінних репродукторах). Породу розводять в 3 племінних заводах ТОВ "Агрікор Холдинг", СТОВ "Ратнівський аграрій", ФГ "Білак" та 3 племінних репродукторах ПСП "Шпанівське", ПАФ "Єрчики", ПОСП "Зірка".

Третя за чисельністю в Україні - волинська м'ясна. 3503 гол, які утримуються у 7 племінних підприємствах, 3 них у племінних заводах - 1516 голів, у племінних репродук-

торах - 304 голови. Розведенням волинської м'ясної породи займаються племінні заводи СТОВ "Васюти", ПЗ СТОВ "Зоря", СТОВ "Пісочне", СТОВ Ратнівський аграрій, ТОВ "Бафффало", ФГ Пчани-Денькович та племінний репродуктор $Ф Г$ "Атлант.

По 8 \% від загальної чисельності у української м'ясної та лімузинської порід. Загальна чисельність поголів'я племінної худоби української м'ясної породи становить 1977 гол., у 2 племінних заводах - 1977 голів. Породу розводять в ДП ДГ "Поливанівка" ДУ ІЗК НААН України, ТОВ "Саан-Агро".

Лімузинська порода є четвертою за представництвом серед зарубіжних селекційних досягнень м'ясного напрямку продуктивності. Загальна чисельність племінного поголів'я цієї породи становить 1909 гол., у 4 племінних підприємствах ,з них у племінних заводах 955, у племрепродукторах 954 гол. Породу лімузин розводять в 2 племінних заводах " ТОВ "Агрікор Холдинг", СТОВ Ратнівський аграрій, в 2 племрепродукторах ТОВ "Бафффало", ФГ "Велес".

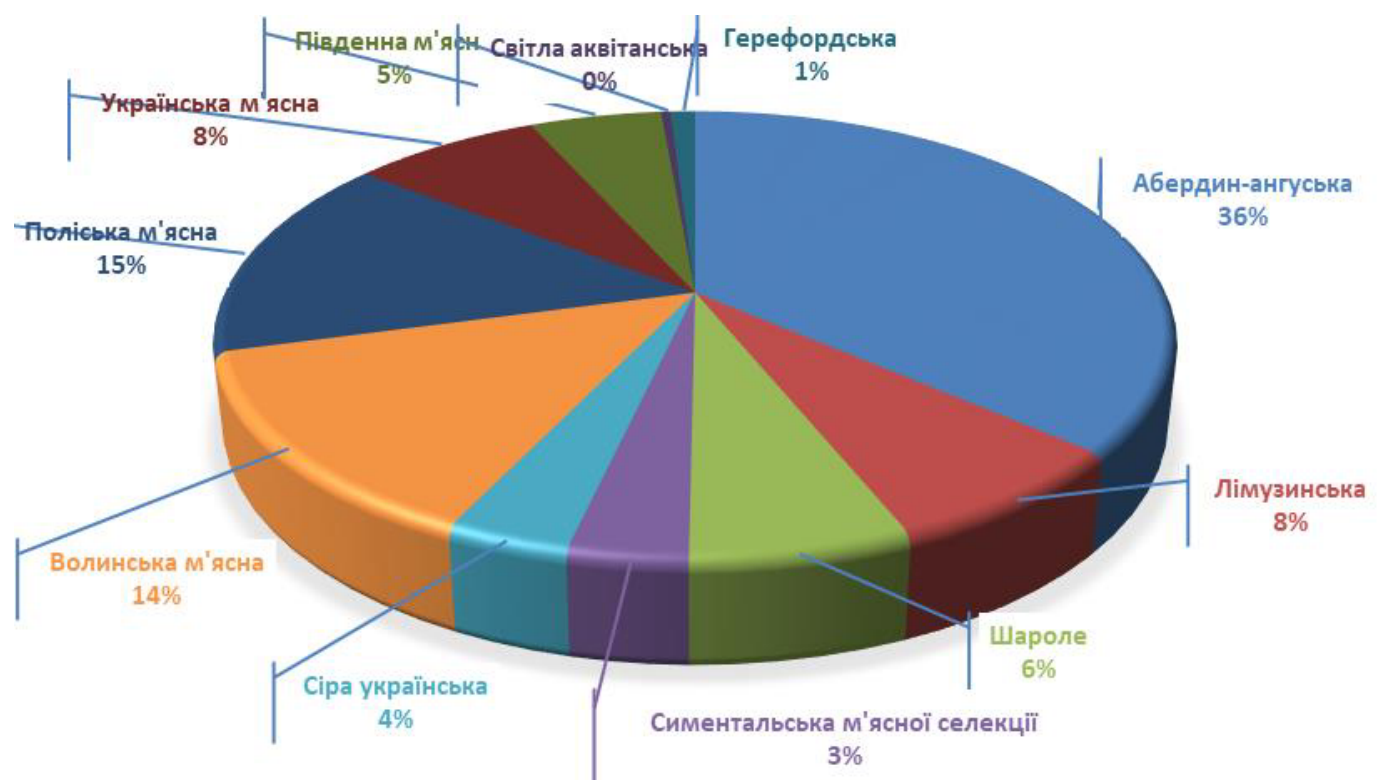

Рис. 2. Питома вага племінної великої рогатої худоби м'ясного напрямку продуктивності вітчизняних та імпортних порід

Сіра українська порода налічує 912 голів, з них у 2 племінних підприємствах (у племінному заводі 740 голів, у племінному репродукторі 172 голови. Породу розводять в племінному репродукторі ДП "ДГ ІТСР імені М.Ф. Іванова "Асканія-Нова" - НННГЦВ та племінному заводі, ДП ДГ "Поливанівка" ДУ ІЗК НААН України.

Симентальську породу м'ясного напряму селекції розводять в племінному заводі ТОВ "Агрікор Холдинг" і 2 племінних репродукторах ТОВ «Бафффало», ТОВ «Добробут». Чисельність симентальської породи м'ясної селекції в Україні становить 879 гол., з них 357 голів зареєстровано у племінному заводі та 522 гол. наявно у племрепродукторах.

Породу шароле розводять в племінних заводах ДП ДГ "Гонтарівка" ІТ НААНУ, ТОВ "Агрікор Холдинг", в племінних репродукторах СТОВ Ратнівський аграрій, ТОВ "Баффало". Загальна чисельність представників породи становить 1627 гол., з них у племінних заводах зареєстровано 869 голів, у племінних репродукторах 758 голів. Питома вага породи за чисельністю в Україні складає $5 \%$.
Потрібно відміти, що за останні 5 років породний склад племінної м'ясної худоби не змінився. У 2015 році до племінного розведення було допущено ті самі 11 порід, що і на початок 2020 року. Але проаналізувавши питому вагу порід за чисельністю хочеться відмітити окремі зміни та тенденції. Абердин-ангуська залишається лідером за чисельністю весь цей час, тоді як чисельність сірої української худоби та симентальської породи м'ясного напряму селекції скоротилася на 14-10\% відповідно в структурі племінного поголів'я. Волинська м'ясна порода навпаки закріпила свої лідируючі позиції і збільшила представництво за чисельністю на 2\%. Починаючи з 2015 року спостерігаємо тенденцію до збільшення поголів'я окремих порід зарубіжної селекції: світлої аквітанської, герефордської, шароле та лімузинської. Остання за 5 років наростила за чисельним представництвом майже 3,5\%.

Висновки. На даний час в Україні зареєстровано 52 племінних господарства, де розводять 11 порід великої рогатої худоби м'ясного напрямку продуктивності, нерівно- 
мірно представлених за чисельністю. За 2019-2020 роки галузь м'ясного скотарства в Україні зазнала втрат, оскільки загальна чисельність племінного поголів'я скоротилась на $7 \%$, а за останні 5 років поголів'я племінної м'ясної худоби зменшилось на 18,20\%. За цей період не підтвердили своїх племінних статусів, реорганізувались та збанкрутували 35 племінних господарств.

Недосконала виробнича база племінних заводів та племінних репродукторів, їх недостатня матеріальнотехнічна забезпеченість, відсутність культурних пасовищ і сталої кормової бази, недостатня державна та інвестиційна підтримка галузі негативно впливають на якість племінних корів і бугаїв та рентабельність ведення м'ясного скотарства. Протягом останніх років реалізація племінного молодняку м'ясних порід на внутрішньому ринку практично не збільшилась. Попит на поголів'я селекції залишається достатньо високим, а якість їх в більшості не відповідає існуючим вимогам та стандартам.

Найбільше поголів'я великої рогатої худоби м'ясних порід зосереджено на півночі та заході країни, де природнокліматичні умови є сприятливими для створення розвинутої галузі м'ясного скотарства. Лідерами за чисельністю являються Волинська та Чернігівська області.

Найбільш чисельною серед імпортованих порід $є$ абердин-ангуська порода. Серед вітчизняних порід найбільшою є питома вага волинської та поліської порід. За період 2019-2020 рр. чисельність племінного поголів'я симентальської та південної м'ясної порід скоротилася відповідно на 32-60\%. Проблему збереження цих унікальних порід необхідно вирішувати на державному рівні. Оскільки південна м'ясна порода $є$ національним надбанням і для України, обов'язком держави є підтримка ії чисельності на рівні, достатньому для ефективної селекційної роботи та підтримання генеалогічної структури породи.

В Україні для створення галузі м'ясного скотарства проведено значну наукову та практичну роботу, але свого потенційно максимального розвитку галузь ще не одержала.

\section{Список використаної літератури:}

1. Генетика, селекция и биотехнология в скотоводстве/ за ред. М.В. Зубця. Київ: «БМПТ», 1997. - 722 с.

2. Державний реєстр суб'єктів племінної справи у тваринництві за 2014 рік / за ред. С. В. Прийми. Київ, 2015. Т. II. 319 c. derjplemreestr_tom2_2014.pdf (animalbreedingcenter.org.ua) 10.20 .2010

3. Державний реєстр суб'єктів племінної справи у тваринництві за 2015 рік / за ред. С. В. Прийми. Київ, 2016. Т. ІІ. 319 c. deriplemreestr_tom2_2015.pdf (animalbreedingcenter.org.ua) 10.10 .2020

4. Державний реєстр суб'єктів племінної справи у тваринництві за 2016 рік / за ред. С. В. Прийми. Київ, 2017. Т. ІІ. 307 c. file:/lanimalbreedingcenter.org.ua/deriplemreestr\%20\%5b\%D0\%94\%D0\%B0\%D $\% 82 \% \mathrm{D} 0 \% \mathrm{~B} 0 \% 20 \% \mathrm{D} 0 \% \mathrm{~B} 7 \% \mathrm{D} 0 \% \mathrm{~B} 2$ \%D0\% B5\%D1\%80\%D0\%B5\%D0\%BD\%D0\%B5\%D0\%BD\%D0\%BD\%D1\%8F\%20 10.10 .2020

5. Державний реєстр суб'єктів племінної справи у тваринництві за 2017 рік /за ред. С. В. Прийми. Київ, 2018. Т. II. 307 c. file://animalbreedingcenter.org.ua/deriplemreestr\% $20 \% 5 \mathrm{~b} \% \mathrm{D} 0 \% 94 \% \mathrm{D} 0 \% \mathrm{~B} 0 \% \mathrm{D} 1 \% 82 \% \mathrm{D} 0 \% \mathrm{~B} 0 \% 20 \% \mathrm{D} 0 \% \mathrm{~B} 7 \% \mathrm{D} 0 \% \mathrm{~B} 2 \%$ D0\% B5\%D1\%80\%D0\%B5\%D0\%BD\%D0\%B5\%D0\%BD\%D0\%BD\%D1\%8F\%20 10.10.2020

6. Державний реєстр суб'єктів племінної справи у тваринництві за 2018 рік / за ред. С.В. Прийми. Київ, 2019. Т. II. 294 c. file://animalbreedingcenter.org.ua/derjplemreestr\% $20 \% 5 \mathrm{~b} \% \mathrm{D} 0 \% 94 \% \mathrm{D} 0 \% \mathrm{~B} 0 \% \mathrm{D} 1 \% 82 \% \mathrm{D} 0 \% \mathrm{~B} 0 \% 20 \% \mathrm{D} 0 \% \mathrm{~B} 7 \% \mathrm{D} 0 \% \mathrm{~B} 2 \%$ D0\%B5\%D1\%80\%D0\%B5\%D0\%BD\%D0\%B5\%D0\%BD\%D0\%BD\%D1\%8F\%20 10.10.2020

7. Державний реєстр суб'єктів племінної справи у тваринництві за 2019 рік / за ред. С.В. Прийми. Київ, 2020. Т. II. 294 c. deriplemreestr tom2 2019.pdf (animalbreedingcenter.org.ua)

8. Каталог бугаїв м'ясних порід і типів племпідприємств України для відтворення маточного поголів'я в 2015 pp / За ред. М.В. Гладія. Київ, 2015. 53 с.

9. Інструкція з бонітування великої рогатої худоби м'ясних порід/ За ред Ю.Ф. Мельника. Київ: Видавничополіграфічний центр «Київський університет», 2003. 24 с.

10. Програма розвитку галузі спеціалізованого м'ясного скотарства України на 1997 - 2005 роки/ М.В. Зубець та ін. - Київ, 1997.113 с.

11. Програма селекції худоби абердин-ангуської породи на період 2003 - 2012 рр. / В.О. Пабат та ін. - Київ, 2005. $343 \mathrm{c}$.

12. Програма селекції худоби волинської м'ясної породи на період 2003 - 2012 роки/ Т.С. Янко та ін. - Київ, 2003.

13. Програма селекції худоби південної м'ясної породи на період $2002-2010$ рр. В.П. Буркат та ін. Київ, 2003. 52 с.

14. Програма селекції худоби поліської м'ясної породи на період 2002 - 2010 ро-ки/ В.М. Білошицький та ін. Київ, 2003. $44 \mathrm{c}$.

15. Програма селекції худоби української м'ясної породи на 2002 - 2010 роки/ А.М. Угнівенко та ін. Київ, 2003. 42 с.

16. Селекційно-генетичні та біологічні особливості абердин-ангуської породи в Україні/ Й.3. Сірацький та ін. Київ, 2002. $203 \mathrm{c}$.

17. Супрун І.О., Гетя А.А. Рубан С.Ю. Перспективи використання генетичних ресурсів м'ясного скотарства в Україні. 2015. Вісник СНАУ Серія Тваринництво Вип. 23(28). С. $42-49$.

18. Угнівенко А.М. Українська м'ясна порода великої рогатої худоби. Київ: Київська правда, 1994.78 с.

19. Supprun I., Getya A., Ruban S., Development Status of Meat Cattle in Ukraine Bulgarian journal of agricultural science. - 2016. - Volume 22, Supplement 1. - pp.140-142.

\section{References:}

1. Biloshytskyi V.M., Melnyk Yu.F., PyshcholkaV.A., 2003. Prohrama selektsii khudoby poliskoi miasnoi porody na peri- 
od2002 - 2010 roky [Polissya beef cattle breeding program for the period 2002-2010]. Kyiv: Ahrarna nauka.

2. Burkat V.P., Vdovichenko Yu.V., Podriezko H.M., 2003. Prohrama selektsii khudoby pivdennoi miasnoi porody na period 2002 - 2010 roky [The program of selection of cattle of southern meat breed for the period of 2002 - 2010]. Kyiv: Ahrarna nauka.

3. Hladiy, M.V. ed., 2015. Kataloh buhaiv miasnykh porid i typiv plempidpryiemstv Ukrainy dlia vidtvorennia matochnoho poholivia v $2015 \mathrm{rr}$ [Catalog of bulls of beefbreeds and types of stud enterprises of Ukraine for reproduction of female livestock in 2015]. Kyiv: Ukraine.

4. Melnyk, Yu. F. ed., 2003. Instruktsiia z bonituvannia velykoi rohatoi khudoby miasnykh pored [Instructions for grading beef cattle]. Kyiv: Ukraine.

5. Pabat V.O., Lytovchenko A.M., Zubets M.V., 2005. Prohrama selektsii khudoby aberdyn-anhuskoi porody na period 2003 - 2012 roky [Aberdeen-Angus cattle breeding program for the period 2003 - 2012]. Kyiv: Ukraine.

6. Pryjma, S. V. ed., (2015). Derzhavnyj reyestr subyektiv pleminnoyi spravy u tvarynnycztvi za 2014 rik [State register of subjects of breeding business in animal husbandry for 2014]. Kyiv: Ukraine.

7. Pryjma, S. V. ed., 2016. Derzhavnyj reyestr subyektiv pleminnoyi spravy u tvarynnycztvi za 2015 rik [State register of subjects of breeding business in animal husbandry for 2015]. Kyiv:Ukraine.file://animalbreedingcenter.org.ua/deriplemreestr\%20\%5b\%D0\%94\%D0\%B0\%D1\%82\%D0\%B0\%20\%D0\%B7\%D0\%B 2\%D0\%B5\%D1\%80\%D0\%B5\%D0\%BD\%D0\%B5\%D0\%BD\%D0\%BD\%D1\%8F\%20

8. Pryjma, S. V. ed., 2017. Derzhavnyj reyestr subyektiv pleminnoyi spravy u tvarynnycztvi za 2016 rik [State register of subjects of breeding business in animal husbandry for 2016]. Kyiv:Ukraine.file://animalbreedingcenter.org.ua/deriplemreestr\%20\%5b\%D0\%94\%D0\%B0\%D1\%82\%D0\%B0\%20\%D0\%B7\%D0\%B 2\%D0\%B5\%D1\%80\%D0\%B5\%D0\%BD\%D0\%B5\%D0\%BD\%D0\%BD\%D1\%8F\%20

9. Pryjma, S. V. ed., 2018. Derzhavnyj reyestr subyektiv pleminnoyi spravy u tvarynnycztvi za 2017 rik [State register of subjects of breeding business in animal husbandry for 2017]. Kyiv:Ukraine.file://animalbreedingcenter.org.ua/deriplemreestr\%20\%5b\%D0\%94\%D0\%B0\%D1\%82\%D0\%B0\%20\%D0\%B7\%D0\%B 2\%D0\%B5\%D1\%80\%D0\%B5\%D0\%BD\%D0\%B5\%D0\%BD\%D0\%BD\%D1\%8F\%20

10. Pryjma, S. V. ed., 2019. Derzhavnyj reyestr subyektiv pleminnoyi spravy u tvarynnycztvi za 2018 rik [State register of subjects of breeding business in animal husbandry for 2018]. Kyiv:Ukraine.file://animalbreedingcenter.org.ua/deriplemreestr\%20\%5b\%D0\%94\%D0\%B0\%D1\%82\%D0\%B0\%20\%D0\%B7\%D0\%B 2\%D0\%B5\%D1\%80\%D0\%B5\%D0\%BD\%D0\%B5\%D0\%BD\%D0\%BD\%D1\%8F\%20

11. Pryjma, S. V. ed., 2020. Derzhavnyj reyestr subyektiv pleminnoyi spravy u tvarynnycztvi za 2019 rik [State register of subjects of breeding business in animal husbandry for 2019]. Kyiv: Ukraine.deriplemreestr tom2 2019.pdf (animalbreedingcenter.org.ua)

12. Siratskyi Y.Z., Pabat V.O., Fedorovych Ye. I., 2002. Selektsiino-henetychni ta biolohichni osoblyvosti aberdyn-anhuskoi porody v Ukraini [Breeding-genetic and biological features of Aberdeen-Angus breed in Ukraine]. Kyiv: Naukovyi svit.

13. Suprun I., Getya A., Ruban S., 2016. Development Status of Meat Cattle in Ukraine. Bulgarian journal of agricultural science, Volume 22. Supplement 1. pp.140-142.

14. Suprun, I.O., Getya, A.A. Ruban, S.lu., 2015. Perspektyvy vykorystannia henetychnykh resursiv miasnoho skotarstva v Ukraini [Prospects of meet cattle using in Ukraine]. Visnyk SNAU Issue. 23(28). pp. 42-49.

15. Uhnivenko A.M., Koropets L.A., Lukianchuk N.V., 2003. Prohrama selektsii khudoby ukrainskoi miasnoi porody na2002 - 2010 roky [The program of selection of cattle of the Ukrainian meat breed for 2002 - 2010]. Kyiv: Ahrarna nauka. ivska Pravda.

17. Yanko T.S., Zubets M.V., Burkat V.P., 2003. Prohrama selektsii khudoby volynskoi miasnoi porody na period 2003 2012 roky [Program of selection of cattle of Volyn meat breed for the period 2003 - 2012]. Kyiv: Ahrarna nauka.

18. Zubets M.V., Pabat V.O., Burkat V.P., 1997. Prohrama rozvytku haluzi spetsializovanoho miasnoho skotarstva Ukrainy na 1997 - 2005 roky [The program of development of the branch of specialized meat cattle-breeding of Ukraine for $1997-2005$ ]. Kyiv: Ukraine.

19. Zubets, M.V. ed., 1997. Henetyka, selektsyia y byotekhnolohyia v skotovodstve [Genetics, selection, biotechnology in livestock breeding]. Kyiv: Ukraine.

Suprun Iryna Oleksandrivna, Ph.D. of Agricultural Sciences, Associate Professor

Dovha Oleksandra Oleksiivna, 2nd year student of the Faculty of Veterinary Medicine

National University of Life and Environmental Sciences of Ukraine (Kyiv, Ukraine)

Development of beef cattle breeding status in Ukraine

In solving international and national agricultural programs, the priority is to preserve the genetic resources of livestock and develop ways to use them effectively, because in the world there is a clear tendency to reduce the breed composition of domesticated species of animals. Therefore, the purpose of our research was to analyze and highlight the current state of tribal beef cattle in Ukraine, as well as the characteristics of domestic breeds, which are the basis for breeding work and forecasting their importance in the breeding process. To analyze the state of development of beef cattle in Ukraine, the State Register of Subjects of Tribal Affairs in Livestock for 2015 - 2019 was used. The research uses methods of system generalization, graphic, analytical and comparativestatistical. The analysis of the state of development of beef cattle breeding in Ukraine was carried out. It is shown that the largest livestock of cattle of beef breeds is concentrated in the north and west of the country, where natural and climatic conditions are 
favorable for the creation of a developed field of beef cattle breeding. It was established that the leaders in terms of number are Volyn and Chernihiv regions, and currently in Ukraine registered 52 breeding farms, where bred 11 breeds of beef cattle. The most numerous among the imported breeds is the Aberdeen and Angus breed. Among domestic breeds the largest is the share of Volyn and Polissia specialized beef breeds. It is shown that in the conditions of prolonged crisis in recent years tribal beef cattle in Ukraine has suffered a significant reduction in the amount, narrowing of the breed structure and changes in the form of ownership. In particular, in the period from 2019 to 2020, the sector of beef cattle in Ukraine suffered losses - the number of breeding herds generally decreased by 7\%/. Some breeds as Simmental and southern meat in amount by 32-60\%.

Key words: meat cattle breeding, breed, domestic breeding, imported breeds, breeding economy, livestock.

Дата надходження до редакції: 12. 01.2021 р. 